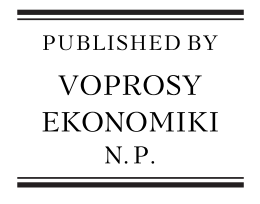

\title{
Fiscal maneuver and restructuring of the Russian economy ${ }^{\text {th }}$
}

\author{
Alexey Kudrin ${ }^{\mathrm{a}, \mathrm{b}}$, Ilya Sokolov ${ }^{\mathrm{c}, *}$ \\ ${ }^{a}$ St. Petersburg State University, St. Petersburg, Russia \\ ${ }^{b}$ Fund "Center for Strategic Research" (CSR), Moscow, Russia \\ ${ }^{c}$ Russian Presidential Academy of National Economy and Public Administration, Moscow, Russia
}

\begin{abstract}
The paper discusses fiscal policy parameters through 2024. The suggested way to ensure long-term fiscal stability is stabilizing both the general government revenues and expenditures as percentages of GDP at levels differing by the public debt service payments and then applying a new version of the fiscal rule. The redistribution of fiscal spending from unproductive to productive areas (primarily investment in human and physical capital) is considered to boost economic growth. The possible use of additional spending on education, public health, and transport systems is presented, as is the optimization of expenditures in nonproductive areas.

(C) 2017 Non-profit partnership "Voprosy Ekonomiki". Hosting by Elsevier B.V. All rights reserved.
\end{abstract}

JEL classification: B22, H21, H30, H41, H51, H52, H54, H55, H56, H61, H62.

Keywords: fiscal policy, fiscal maneuver, state budget, productive expenditures, budget expenditures structure, structural reforms, economic growth.

\section{Short-term and long-term fiscal policy objectives}

The Russian economy has faced serious problems in the past few years. The physical GDP was lower during Q1 2017 than at the beginning of 2012. In other words, the production is in a state of long-term stagnation. Of course, this situation can be partially attributed to negative external factors: the sharp drop in oil prices in 2014 and foreign sanctions. However, Russia's economic problems are mostly internal in nature. This is evidenced by the fact that the deceleration

\footnotetext{
t The updated English version of the article published in Russian in Voprosy Ekonomiki, 2017, No. 9, pp. 5-27.

* Corresponding author, E-mail address: email: Sokolov@iep.ru

Peer review under responsibility of Voprosy Ekonomiki.
} 
started as early as 2013, when GDP growth was at a low rate of $1.3 \%$, and continued to slow down during the first half of 2014. The situation is aggravated by the emergence of new but entirely expected challenges. For example, in 2017, Russia entered a long period of deteriorating demographic performance; the workforce will decline by $0.5 \%-0.7 \%$ per year over the next 10 years, threatening an additional deceleration of economic growth to 0.5 percentage points ("p.p.") during the period (Ivanova et al., 2017). Analysts are unanimous in predicting a lengthy stagnation of the Russian economy unless serious structural reforms are undertaken. According to the baseline scenario put forth by the Russian Ministry of Economic Development, from 2017 to 2020 Russia's GDP growth will average $1.6 \%$ per year, while the IMF estimates an average annual growth rate of $1.5 \%$ over the next six years.

Dramatic problems have arisen in the state budget system as well. Thus, due to falling oil prices, oil and gas revenues declined almost by half in real terms ${ }^{1}$ during 2016, compared to 2014. However, problems have also been identified in non-oil-and-gas revenues, as declining production has led to a reduction in the main tax base. The law on the federal budget for 2014-2016 was based on a GDP growth rate of $9.7 \%$ in three years; however, production actually dropped by $2.3 \%$. The total revenues in the state budget were $15 \%$ lower in real terms during 2016 than in 2013, and 24\% lower than the government predicted in the Main Guidelines of Fiscal Policy for 2014-2016.

Budgetary problems also appeared prior to the latest drop in oil prices. Per Goryunov et al., 2013, the budget deficit (the excess expected long-term reduced amount of future expenditures over the corresponding future revenues) was estimated at $8.4 \%$ of GDP. ${ }^{2}$ In a later publication (Goryunov et al., 2015), due to the sharp reduction in current and expected oil prices, the estimated budget deficit increased to $13.6 \%$ of GDP. Thus, falling oil prices only aggravated the longterm budget imbalances.

An increase in the budget deficit will be caused by a reduction in state revenues (their long-term estimate is $27.8 \%$ of GDP, compared with an average of $32.8 \%$ in 2015 and 2016) and an increase in governmental expenditures (the average long-term value is estimated at $41.5 \%$ of GDP, compared to $36.4 \%$ over the past two years). If the current fiscal regime is maintained over the long-term, the current deficit in the general government budget at 3.5\% of GDP (the average over the past two years) will increase by another 10 p.p. of GDP, of which 5 p.p. will be attributable to decreasing budget revenues, and the remaining 5 p.p. will be attributable to the unavoidable growth in expenditures. This may lead to a drastic increase in the national debt, which could snowball into a debt crisis.

To avoid this scenario, the basic provisions of current fiscal policy must be thoroughly revised. Changes must be directed towards three correlated tasks:

- restoring short-term and long-term budget balance and risk protection;

- ensuring long-term budget stability; and

- creating favorable conditions for economic growth.

\footnotetext{
${ }^{1}$ Unless specifically stated, indicators stated in real terms are calculated using domestic demand deflators which, in our opinion, ensure the best possible estimate of the purchasing power of budget funds.

2 The budget deficit is calculated based on long-term discounted forecasts of revenues and expenditures for the state budget and the GDP.
} 
To solve the first problem, we must overcome the consequences of sharply lower oil prices, which have resulted not only in a larger budget deficit but also an almost complete depletion of the Reserve Fund. To ensure the reliable performance of budget obligations, we need, on the one hand, to bring budgetary expenditures in line with revenues as soon as possible, and on the other hand, to replenish the Reserve Fund, which has been depleted over the past several years. Presumably, the minimum asset reserve adequacy ratio is determined by the Budget Code during the creation of the Reserve Fund (it is 7\% of the GDP). ${ }^{3}$

The government is taking active steps to adapt fiscal policy parameters to the new reality. Federal budget expenditures for 2017-2019 should be reduced by $13 \%$ in real terms, while expenditures in the state budget system should be reduced by $14 \%$ (in both cases, deflation is calculated based on the CPI), allowing fiscal policy parameters to be adapted to low oil prices by 2020. Combining the National Welfare Fund with the Reserve Fund will provide temporary protection for the federal budget from external shocks, while the new fiscal rule will create the conditions required to accumulate additional reserve assets if oil prices rise above conservative predictions (USD 40 per bbl, indexed at $2 \%$ per year, beginning in 2018).

However, in our opinion, the new fiscal rule proposed by the government is excessively harsh, and it should have accounted for the need to finance structural transformations. As a compromise (interim) version of the fiscal rule, the base oil price can be set at USD 45 per bbl, to be indexed by the value of USD inflation, and marginal expenditures can be increased by the value of proceeds from privatization over the next three years up to $0.5 \%$ of GDP. This softening of the fiscal rule will not increase fiscal risks, as both prices (USD 40 and USD 45 per bbl) are close to the lower limit of the current consensus near-term forecast of oil prices (USD 50-60 per bbl) per international organizations (IMF, World Bank, International Energy Agency, U.S. Energy Information Administration, and OPEC). At the same time, as reserves are accumulated, and for fiscal policy to take on a more pronounced counter-cyclical nature, a certain tightening of the fiscal rule is quite justified. In particular, it is expedient to forego the "privatization premium" on expenditures afterwards and to switch to a zero initial balance.

Of course, the goal of fine tuning fiscal rules is not only to reduce government expenditures but to do so without damaging the direct and indirect beneficiaries of budget payments (i.e., individuals, budget-funded organizations, and businesses). To this end, we must systematically identify the reserves of the budget economy, eliminate inefficient expenditures, and improve financing mechanisms in the budgetary network and public sector of the economy. The main areas of these efforts are formulated in the report by the Russian Ministry of Finance (2015).

The greatest potential for reducing expenditures without significant negative consequences lies with structural reforms. Accordingly, to successfully address the first task, transformations are required in budget-funded sectors that improve the ratio of government expenditures to results achieved.

The second task is to stabilize the budget balance after achieving short-term balance. In other words, the huge deficit between future revenues and expendi-

\footnotetext{
${ }^{3}$ The matter of determining the minimum admissible amount of accumulated reserve assets requires additional rationale.
} 
tures must be quickly reduced. The downward trend of future budget revenues (as a percentage of GDP) is caused first by comparatively low hydrocarbon production and export. The global demand for hydrocarbons is rising considerably slower than the global economy as a whole, which leads to the fundamental weakness of the commodity-based model that is characteristic of Russia. However, the worst part is that our country is gradually losing its position in the natural gas market: Russia's share of global production fell from $22.0 \%$ in 2000 to $16.3 \%$ in 2016 , and continues to fall (gas production in Russia grew by $0.6 \%$ per year on average during the period). Oil production in Russia also demonstrates a slow trend; for the past 10 years, the average annual rate of production growth was only $1.3 \%$, compared with $4.8 \%$ during the preceding decade. According to a forecast by the International Energy Agency, production will begin to decline by 2020 .

As for growing expenditures, the main driver is the aging population. This trend is common in all countries. However, Russia is far behind in recognizing the seriousness of the problem and has not yet initiated measures to protect the budget system from its consequences (Kudrin and Gurvich, 2012).

Thus, the second task is related to the need to mitigate the consequences of accumulated structural problems. It can be solved in many ways, differing in the set of measures for increasing revenues and cutting expenditures and in the specific content of those measures. It should be noted that the first two tasks are important not only in terms of the fiscal policy itself; we cannot expect an acceleration in economic growth. The growing gap between the government's revenues and expenditures from an investors' point of view points to a possible tax increase, which may devalue the investments made. Thus, ensuring short-term and longterm budget stability is an essential condition for overcoming uncertainty with respect to the country's future fiscal regime and, accordingly, for winning investor confidence, without which it will be impossible to activate the capital accumulation process.

The third task (i.e., supporting economic growth) has been attracting an increasing amount of attention lately. Amid stagnation following the international financial crisis of 2008 and 2009, many countries agreed, for example, to increase public investments in infrastructure to revitalize economic activity (IMF, 2014; Mourougane et al., 2016). The OECD, the IMF, and other international organizations also pay significant attention to these matters. According to their surveys, fiscal policy is capable of accelerating economic growth by both increasing macroeconomic stability (this aspect has been studied fairly well; see IMF, 2015a, $2015 \mathrm{~b}$ ) and improving the structures of taxes and public expenditures. The latter can support the investment process and labor activity, improve the level of employee education (and, accordingly, the quality of human capital), and accelerate the growth of total factor productivity.

As shown in the study conducted by the IMF (2015b), the positive potential of fiscal reforms is sufficiently high; in developed countries, they accelerated GDP growth by 0.75 p.p. on average. In developing countries, the positive effect of those reforms is even greater, amounting to 2.5 p.p. on average. This effect manifested itself in most countries that carried out budget reforms; in $60 \%$ of the cases, economic growth accelerated following comprehensive fiscal reforms.

It should be noted that Russian economists have posed a question regarding the expediency of a budget maneuver on multiple occasions, and most systematical- 
ly in the Strategy-2020 (Mau and Kuzminov, 2013; Idrisov and Sinelnikov-Murylev, 2013). Today, the need for such a maneuver has become especially pressing.

\section{The correlation between fiscal policy and economic growth: theoretical and empirical analysis}

Contemporary theoretical concepts regarding the correlation between the overall fiscal policy parameter and economic development are based mostly on the works of R. Barro, within the framework of the endogenous growth theory (Barro, 1990). His model accounts for the fact that certain government expenditures make a positive contribution to economic development by reducing production expenses or by improving the utilization efficiency of production factors. At the same time, maintaining high budget expenditures requires a corresponding level of tax burden which, in turn, has a negative effect on growth. Therefore, the total effect of a fiscal policy is determined by a combination of the amount and structure of revenues and expenditures for the budget system.

In the baseline model, expenditures are divided into productive (increasing potential output) and non-productive (other). Productive expenditures include investments in human and physical capital, expenses for fundamental research, and other related expenses. Non-productive expenditures traditionally include expenses for social security, national defense, law enforcement, and partly for public administration, which, from an economic point of view, all represent a redistribution of resources between population groups without having a significant positive effect on economic growth. On the whole, productive expenditures can be said to contribute to development for stable future economic growth, while non-productive expenditures are attributed to the daily functions of the state or current consumption.

Taxes are also divided into two main types: non-distorting and distorting. Nondistorting taxes include lump sum taxes, which do not vary based on the actual results of a firm's operations. It should be considered that all taxes actually used in an economy distort the actions of its participants in one way or another, thereby slowing economic growth.

The main conclusions from Barro's model can be formulated as follows:

- if funded through lump sum taxes, increased productive expenditures create conditions for long-term economic growth;

- if funded through lump sum taxes, increased non-productive expenditures have no effect on long-term growth rates; and

- all other conditions being equal, increased distorting taxes reduce growth rates.

By combining these provisions and discarding the purely speculative opportunity to generate revenues by levying only lump sum taxes, it can be concluded that: (a) increased non-productive expenditures decrease long-term economic growth and (b) the dependence of long-term economic growth rates on the amount of productive expenditures has a certain threshold value-increasing those expenditures up to a certain limit accelerates growth, but once that limit is exceeded, growth decelerates. For every country, there is an optimal level of productive expenditures, at which the expenditures' positive effect is balanced by the negative impact of taxes. The expediency of non-productive expenditures should be discussed based on other considerations (e.g., in the case of social policy, the im- 
portance of fighting poverty). However, from an economic development point of view, they are associated with a net loss in the GDP growth rate.

The general conclusion from the endogenous growth models is that fiscal policy may have a considerable effect not only on production volumes but also on the rate of economic growth; however, opportunities for this effect are limited by the "price" to be paid in the form of an additional tax burden. Another important finding from theoretical analysis should be noted (i.e., that any discussion of fiscal policy effects should always consider the structure of public expenditures - the extent to which they are aimed at maintaining growth — and the taxes from which expenditures are funded).

In the long run, to which Barro's models are oriented, the reduced value of total budget revenues and expenditures for all years cannot differ significantly. However, during certain periods a considerable budget deficit may be realized, which does not allow the negative consequences of distorting taxes to be avoided. For example, Adam and Bevan (2005), based on a panel including 45 developing countries, demonstrated that a significant deficit considerably slows economic growth.

The negative effect of a budget deficit on the economy (especially in developing countries) is caused by accelerated inflation and respective negative consequences for savings rates, interest rates, and subsequent consequences of these factors. The empirical proof of a significant connection between budget deficits and inflation are presented, in particular, in Catão and Terrones (2005) and Lin and Chu (2013).

The first theory about the connection between budget expenditures and economic growth was voiced by A. Wagner (1958 [1883]). Analyzing public expenditure trends, he noted that they grew faster as per capita income increased. Thus, the ratio of budget expenditures to GDP increases gradually, which can be interpreted as a trend toward an "increasing role of government." This dependence can be attributed to various factors: a) the government is increasing its involvement in certain socially important functions (e.g., education and health care); b) as the economy develops, its need for regulation increases (e.g., in relation to natural monopolies); c) growing per capita revenues are accompanied by an aging population, requiring additional social policy expenditures; and d) labor productivity grows considerably slower in the public sector than in the market sector, so that, for a given proportion of goods and services production, the share of employment in the public sector increases gradually.

Another mechanism of correlation between the level of economic activity and public expenditures was proposed by J. M. Keynes: they stimulate production when demand reduces. As a result, budget expenditures are also related to the size of GDP; however, the logic is of a contrary nature - the causal direction runs from expenditures to production.

Finally, the third hypothesis is that increasing expenditures creates the need to raise taxes and borrow more, which slows down economic growth.

Thus, different concepts about the connection between public expenditures and the level of economic activity point to its differing quantitative and qualitative properties. Of course, Keynes's theory speaks mostly about short-term and mediumterm effects, while other concepts point to long-term effects. However, in any case, the principal divergence between the versions is evident: according to Keynes, 
budget expenditures act as an indicator controlled by the government; according to Wagner, budget expenditures follow public demand, which, in turn, depends on the size of GDP; in the third concept, the connection is rather bi-directional.

Attempts to validate Wagner's law lead to ambiguous results. By comparing constructed models, economists became convinced that the findings were not sufficiently stable and changed depending on the choice of country, period analyzed, and econometric analysis method.

A new approach has become common in recent years, which studies the longterm co-integrational relationship between budget expenditures and the GDP (see, e.g., Lamartina and Zaghin, 2011; Bayrak and Esen, 2014). The direction of the cause-and-effect dependence is not postulated beforehand but is estimated additionally. Many papers study data on groups of countries, in some cases combining them into panels, producing a broader picture. These groups include developed countries of the OECD or EU in some cases, and both developed and developing countries in others. This approach produced sufficiently defined and consistent results, which can be summarized as follows.

1. Many countries demonstrate a long-term co-integrational relationship between budget expenditures and size of GDP.

2. In developing countries and transitional economies, the elasticity of expenditures relative to GDP is much higher than in developed countries. This means that countries in early stages of development are characterized by a gradually increasing ratio of budget expenditures to GDP, while in developed countries, this ratio remains relatively stable.

3. The direction of the cause-and-effect dependence most often moves from GDP to budget expenditures (according to Wagner's laws) and is bi-directional in certain cases. As a rule, a significant long-term effect of government expenditures on the volume of production cannot be identified. A multi-country analysis also shows that budget expenditures should be regarded more as indicators shaped by public demand or determined by the balance between interests of influential groups than a set (controlled) parameter (in the spirit of Keynes's theory). However, this does not mean that government expenditures cannot be used as economic policy tools. The more likely conclusion is that budget parameters are closely connected with other characteristics of the economy, and their corrections should be considered in combination with other transformations as part of a comprehensive program of economic reforms.

Below we consider the results of an empirical analysis of the impact individual types of taxes and budget expenditures have on the economy. The positive effects of increasing productive expenditures and the negative effects from distorting taxes, predicted by economic models, find convincing evidence. Research demonstrates that increasing productive expenditures has the greatest impact on production growth when it is balanced by reducing other expenditures or raising non-distorting taxes. In this case, an increase in productive expenditures by 1 p.p. of GDP considerably accelerates economic growth, raising its annual rate by 0.26 p.p. (Gemmell et al., 2011). This is a long-term effect that most often takes four to five years to fully manifest itself.

As evidenced by a multi-country analysis, an improvement in the budget expenditure structure produces a positive effect only if certain additional conditions are met (i.e., ensuring macroeconomic stability, pursuing an open economy policy, 
and creating favorable conditions for private investments). The effect of a budget maneuver is intensified considerably if accompanied by several structural reforms.

\section{The Russian budget system: Trends and prospects}

Fig. 1 shows trends for the basic parameters of the Russian budget system. Simple regressions lead to the following conservative conclusions.

1. Budget system revenues demonstrate a significant downward trend, declining by 0.36 p.p. of GDP on average. This is caused specifically by a change in trading conditions and deteriorating hydrocarbon production.

2. The general trend is affected by fluctuations in oil prices, for which a USD 1 per bbl change leads to a change in revenues equal to 0.04 percent of GDP. It should be noted that these estimates result from changes in the size of both revenues and GDP.

3. Expenditures demonstrate a slight long-term upward trend (seemingly reflecting the increase in per capita revenues).

4. A short-term decrease (increase) in GDP per capita increases (decreases) expenditures as a percentage of GDP. This apparent contradiction is explained by the fact that on a one- or two-year horizon, budget expenditures are more stable than the size of GDP.

The socioeconomic development strategy for the period through 2035, developed by the CSR (hereinafter, the Strategy), contains two versions of the macroeconomic forecast. The first (baseline) version, used mainly for comparison, proposes maintaining current institutional conditions (i.e., in fact, inertial development). The second version (target) allows for the implementation of a wide range of structural and institutional reforms. Both scenarios assume that prices for Urals oil will be USD 50 per bbl in 2017, and USD 52 to USD 55 per bbl in 2018 and 2019 , remaining practically unchanged in terms of constant USD prices thereafter, signifying growth in nominal prices by roughly $2 \%$ per year. They will reach USD 62 per bbl by 2024 and USD 77 per bbl by 2035 .

In the baseline scenario, all key indicators grow comparatively slowly-GDP growth rates in the most "successful" years do not exceed $2.5 \%$, amounting to $2.1 \%$ on average. Overall, by 2035, GDP will increase by only 50\% compared to 2016 .

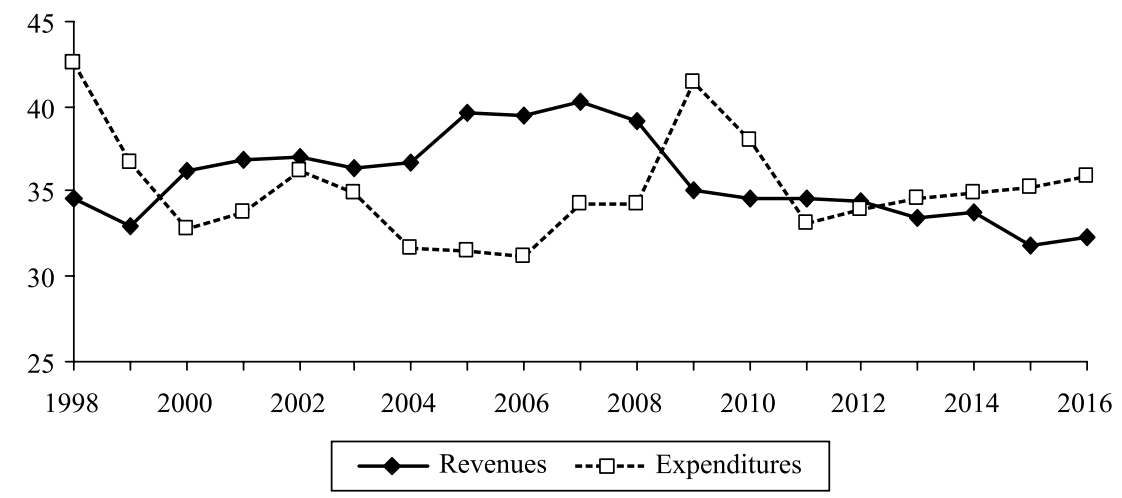

Fig. 1. Budget system parameters (\% of GDP).

Sources: IMF; Russian Ministry of Finance; authors' calculations. 
In the target scenario, significantly better results are expected. The reforms undertaken should consistently ensure increased labor productivity. Forecasted average annual GDP growth rates will reach 2.4\% from 2017 to $2020,3.7 \%$ from 2021 to 2025 , and $4.0 \%$ from 2026 to 2030 . Afterwards, due to the achievement of a higher GDP, production growth will slow down slightly to $3.7 \%$ from 2031 to 2035. Overall, during the period from 2017 to 2035, the physical GDP will double under this scenario.

In both scenarios, budget system revenues lag the GDP trend considerably. For example, in the baseline scenario, the average rate of budget revenue growth was estimated at $1.7 \%$ per year in real terms, while overall they will increase by only $37 \%$ over the forecast period. Simultaneously, the ratio of public expenditures to GDP will decrease to $30.8 \%$ by 2035 (compared with $32.2 \%$ in 2016).

In the target scenario, public expenditures as a percentage of GDP decline even further by the end of the period (to 30.4\%); however, in real terms, this growth turns out to be much higher $(70 \%)$. In both scenarios, oil and gas revenues fall quickly (to approximately $3.5 \%$ of GDP by 2035), while non-oil and gas revenues grow slightly faster than GDP (due to a smaller share of the oil and gas sector, the base for other taxes increases).

According to our estimates, maintaining the government spending policy pursued in recent years will force budget expenditures to increase to $41.5 \%$ of GDP by 2035 (compared to $35.9 \%$ of GDP in 2016). This increase will be driven mainly by increased social spending, plus spending on health care and on servicing national debt (growing budget expenditures will require constantly increasing borrowing). The estimates obtained may seem exaggerated. However, they are extrapolating the trends observed in recent years. Specifically, the ratio of social policy expenditures to GDP increased from 8.8\% in 2006 to $12.7 \%$ of GDP in 2016 (i.e., nearly $50 \%$ ). Over the long-term, the main challenge for the budget will be the aging population, which drives inevitable spending increases for pension and medical services. According to IMF estimates, this will require Russia (unless the necessary reforms are carried out) to increase social expenditures for pension services and health care by 4.5 p.p. of GDP from 2022 to 2050 (IMF, 2017).

When the inertial scenario leads to an excessive widening of the gap between budget system revenues and expenditures, the second of the three problems outlined above (i.e., ensuring long-term budget stability) becomes quite difficult to solve. To achieve this goal, it appears expedient to stabilize the level of revenues and expenditures as a percentage of GDP. This is a compromise between the anticipated rise in demand for social services, public investments, and so forth, following economic growth and the predicted fall in revenues (as a percentage of GDP). Stabilizing revenues and expenditures will yield great advantages; this approach is significantly more stable in the long run than the other options, which, eventually, face natural limitations. For example, a gradual increase in revenues as expenditures grow will cause the economy to slow down due to the excessive tax burden, while budget consolidation in response to a stable reduction in budget revenues, as global experience shows, cannot last long (let alone contradict Wagner's law).

Choosing a level at which maintaining budget revenues and expenditures is expedient is not a trivial challenge. Global experience offers no easy answer, as levels of revenues and expenditures differ considerably between country groups. 
However, the dispersion of values is extremely wide, even within a single group with similar GDP per capita. For example, from 2012 to 2016, average budget expenditures were $42 \%$ of GDP in Poland, but only $26 \%$ in Malaysia, which is similar to Poland in terms of level of economic development. In Brazil, public expenditures were $39 \%$ of GDP, while they totaled $27 \%$ in Mexico, located in the same region and falling within the same per capita income range. Fig. 2 shows the respective average data for 2012 through 2016, for a sample of large developing countries.

In choosing a long-term expenditure level, we followed the assumption that, in 2019, budget consolidation would be mostly complete (i.e., current revenues and expenditures will be brought in line with each other). By that time, according to the government's forecast, consolidated budget expenditures should decrease to $33 \%$ of GDP. Subsequently, according to the Strategy, the next stage of reform should start, at which point expenditures will even out around 34\% of GDP. One condition for long-term stability is the consistency of revenues with primary expenditures (33.0\%-33.2\% of GDP). It is vital that the reforms not allow a further increase in expenditures and make it possible to earn the stated amount of revenues within a business cycle on average.

A moderate increase in certain taxes is possible here, while having a minimal distorting effect on the economy. First, it is advisable to complete the tax changes initiated in the oil and gas sector in 2015 by reducing the export duty on oil and petroleum products to zero, to be fully offset by raising the mineral extraction tax on oil. Another possible step is a gradual discontinuation of unreasonable tax benefits to mitigate the inequality in economic conditions for different companies, which distorts fair competition. Tangible results can be produced by further improving tax administration by simplifying and accelerating procedures, reducing the administrative burden on taxpayers during tax audits, and adapting tax legislation to new business realities (improving laws on taxing e-commerce and hybrid instruments).

The level of budget expenditures can be stabilized concurrently with structural improvements. The general approach is that productive expenditures should be increased, while others should be reduced, to offset and stabilize expenditures. The parameters of budget changes are reviewed in detail in the next section.

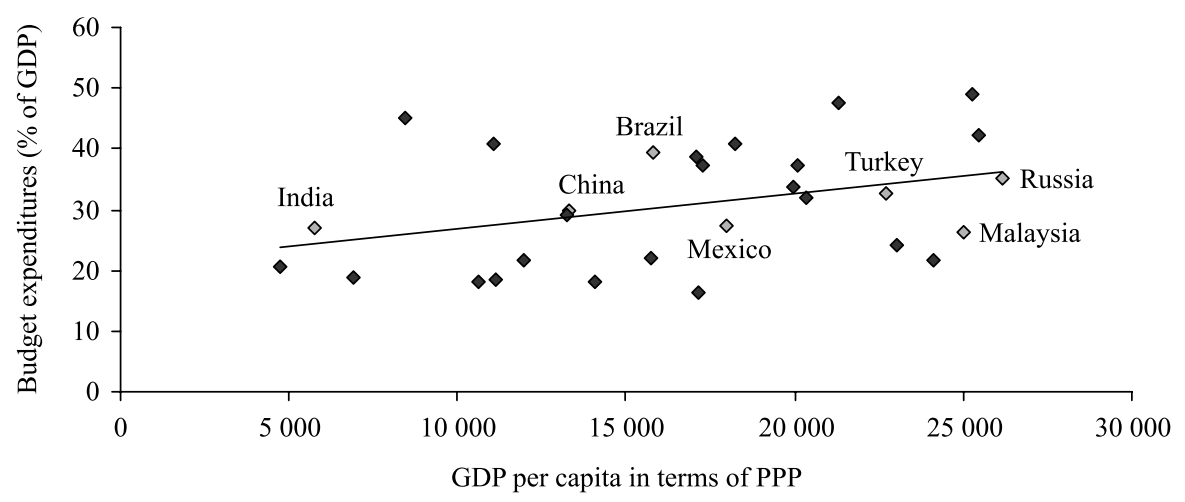

Fig. 2. Budget expenditures and GDP per capita on average, 2012-2016. 


\section{Adjusting the expenditure structure}

The areas for changing expenditures and the amount of change should account for several criteria, such as the impact of expenditures on economic growth, comparable levels relative to countries with similar budget sector organization and social services quality, the opportunity to carry out structural transformations within an industry, and so forth. The prerequisites for increasing the specific weight of specific budget expenditures (determined by functional or economic classification) are represented by the following conditions:

- substantial positive effect of expenditures on the economy;

- priority for the population;

- comparatively low levels by global standards; and

- possibility of sufficiently quick structural reforms that ensure the effective utilization of additional funds.

Arguments in favor of reducing the specific weight of any single area of expenses include the following conditions:

- a negative or neutral effect of expenditures on the economy;

- comparatively low household demand for the respective public services;

- increased levels of expenditure relative to comparable countries;

- the ability to carry out structural reforms capable of fully or partially offsetting lower government expenditures;

- clear inefficient utilization of the portion of funds in the area under review; and

- a temporarily increased level of expenditures (as a rule, it is easier to bring expenditures back to the typical state than to reduce them within the current long-term level).

It is expedient to estimate the impact of expenditures on economic growth based on a combination of theoretical findings and empirical analysis. Below are some of the most relevant results from recent multi-country studies.

Judging by the results of the empirical analysis, public investments in developing social infrastructure offer the highest potential for accelerating economic growth. Developing transportation or water supply systems will lead to reduced production costs (i.e., an improvement in the economy's competitive performance). One important condition for achieving a positive impact from public investments is that they should complement and encourage private investments, rather than replace them. The positive impact of public investments on production both in the short run (due to demand effects) and in the long run (due to the supply effect) is supported by evidence from many studies (see, e.g., Barbiero and Cournède, 2013).

At the same time, it is not easy to make a straightforward assessment of the quantitative parameters, since the results depend on many factors from the phase of the economic cycle to the methods for funding public investments. The efficiency of the procedures for selecting and subsequently monitoring investment projects is especially important; according to IMF estimates, around one-third of expenditures for public investments are lost, on average, due to inefficient implementation of investment projects. The positive impact of public investments on the economies of the most successful countries in this respect is twice the effect of invested budget funds in the least efficient countries (IMF, 2014). Thus, improving the implementation quality for national investment projects is as important as increasing expenditures for infrastructure development. 
Education expenditures improve the quality of human capital and, as shown by multiple studies, have a positive effect on economic growth (see Acosta-Ormarchea and Morozumi, 2013; Barbiero and Cournède, 2013; and so forth). In particular, Baldacci et al., 2008, discovered a significant positive effect from such expenditures on growth rates in developing countries. At the same time, two-thirds of the effect are manifested during the first five years, whereas the remaining part is realized over the next five years. The multi-country analysis provides evidence that, in $25 \%$ of cases, an increase in the specific weight of education spending is followed by a noticeable acceleration of growth.

Increasing government expenditures for health care leads primarily to lower disease and mortality rates in the population, which eventually result in longer life expectancy (and a healthier life span). A larger workforce and higher quality of human capital also encourage accelerated economic growth (Afonso and Jalles, 2013; Aghion et al., 2010). According to IMF (2015b) estimates, increased expenditures on health care are followed by accelerated output growth in $40 \%$ of cases (i.e., more often than after increasing any other expenditures).

The evidence of negative consequences of increasing non-productive expenditures is just as strong. These consequences have been demonstrated for social transfers (e.g., in Acosta-Ormaechea and Morozumi, 2013; Afonso and Jalles, 2013). Several works discovered that greater government consumption and a larger public-sector payroll fund have a negative effect on economic growth (Afonso and Jalles, 2013).

It should be noted specifically that there is danger in government allocation of subsidies (except when they are aimed at correcting market gaps). Subsidies distort the distribution of economic resources and limit market competition (OECD, 2001). Moreover, they are mostly allocated to contracting sectors of the economy (often in critical condition), protecting low-productivity companies and slowing down the necessary redistribution of resources toward more productive utilization. It should be noted that Fournier and Johansson, 2016 show an unexpectedly large negative impact from such subsidies; an increase in their share of total budget expenditures by 1 p.p. reduces potential annual GDP growth rates by $0.1 \%$.

Below, we review changes in Russia's budget expenditures in the main industry sectors and make an international comparison of their sizes and structures. The distribution of the Russian budget system expenditures between productive and non-productive expenditures is shown in Fig. 3. The size of productive budget expenditures is stable enough, between $10.5 \%$ and $11.0 \%$ of GDP. The exceptions occur during crisis periods, when productive expenditures grow because of counter-cyclical policy measures. At the same time, the specific proportion of productive expenditures demonstrates a clear downward trend, declining by 0.2 p.p. per year on average.

The international comparisons used IMF data related to 2014, according to the COFOG classification, which differs slightly from the Russian classification of expenditures. The expenditure indicators for Russia were compared to average indicators across three country groups: developed, transitional economies of Central and Eastern Europe (CEE), and large developing countries. As seen in Fig. 4a, Russia is close to the developing countries in terms of productive expenditures and lags the other groups. However, it stands out in terms of the specific proportion of productive expenditures out of total budget expenditures for the general government; according to COFOG, this share is only $21 \%$ in Russia, compared with $30 \%$ and more, on average, in other country groups (Fig. 4b). 


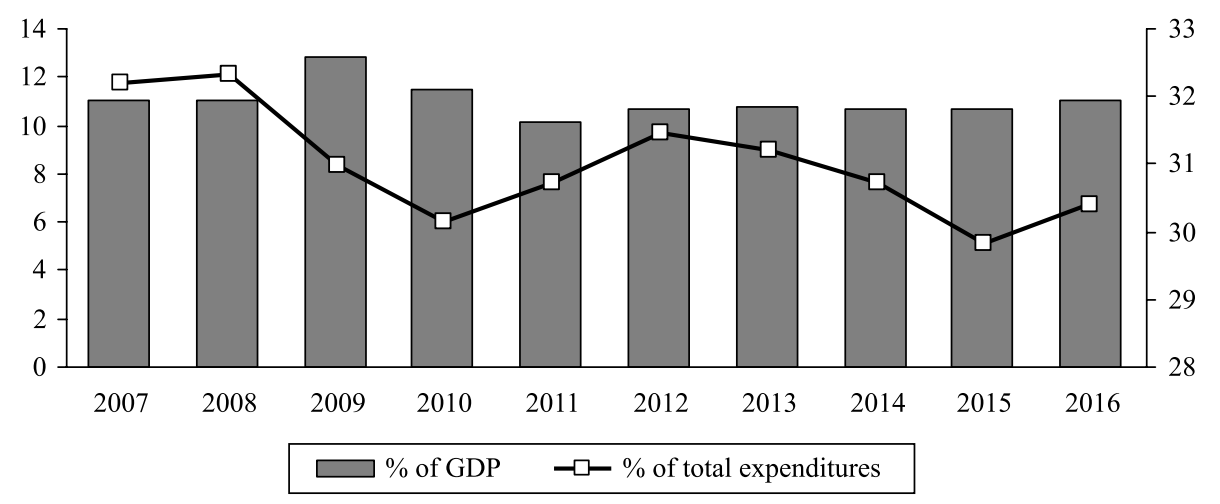

Fig. 3. Productive expenditures in the Russian budget system.

Sources: Russian Ministry of Finance; authors' calculations.

The comparison is similar for education and health care. Russia lags developed and CEE countries in terms of these expenditures as a percentage of GDP but surpasses developing countries (Figs. 5a, 6a). In terms of budget expenditure structure, Russia lags all three country groups (Figs. 5b, 6b).

The reverse situation is observed for law enforcement and defense expenditures. Here, Russia shows higher figures for both the size of expenditures as a percentage of GDP (Figs. 7a, 8a) and their specific proportions (Figs. 7b, 8b).

In terms of social protection expenditures, Russia lags developed countries and the CEE but is ahead of developing countries. In both cases, this is related to expenditures as a percentage of GDP and the specific proportion of those expenditures (Fig. 9).

The only large category of expenditures where Russia does not stand out from other countries is expenditures on the national economy. However, comparisons can be complicated, as this category contains a combination of heterogeneous expenditures, from infrastructure investments that have a high positive effect to subsidies that have a negative impact on the economy.

Overall, Russia has a specific structure of budget expenditures. It combines expenditures for developing human capital (education and health care), which are

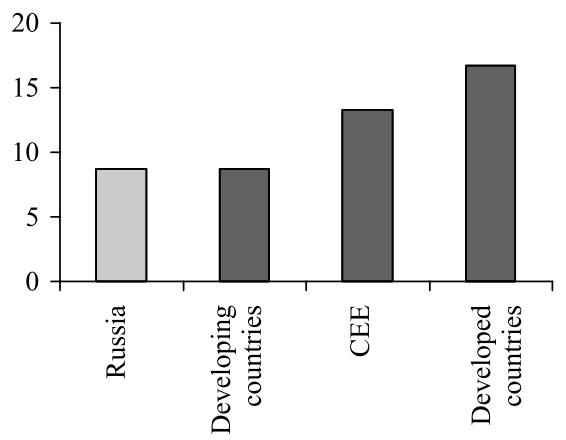

Fig. 4a. Productive budget expenditures (\% of GDP).

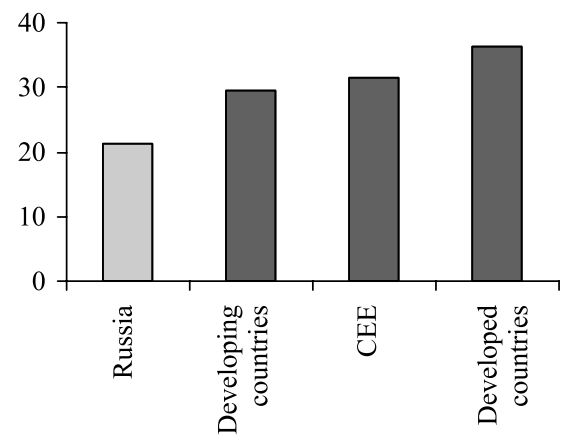

Fig. 4b. Proportion of productive budget expenditures out of total expenditures for the general government (\%). 


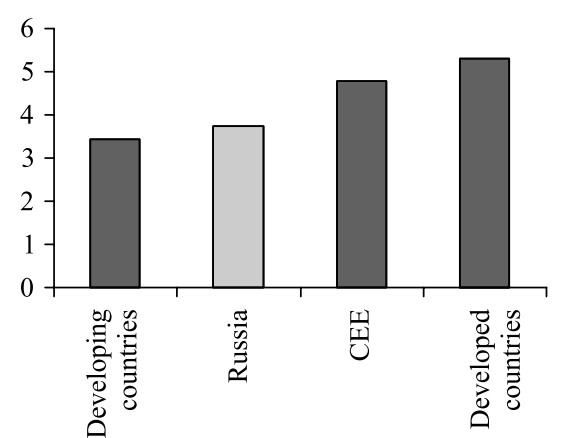

Fig. 5a. Budget expenditures on education ( $\%$ of GDP).

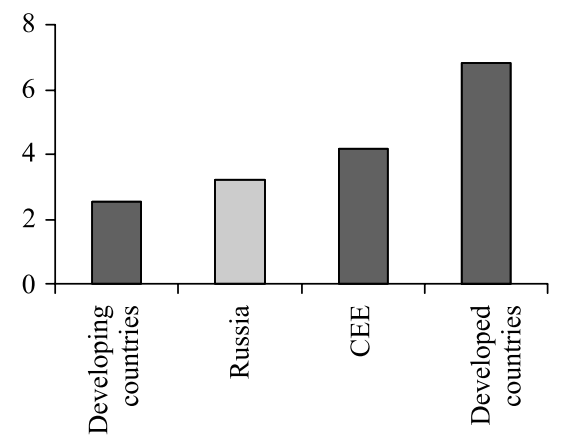

Fig. 6a. Budget expenditures on health care (\% of GDP).

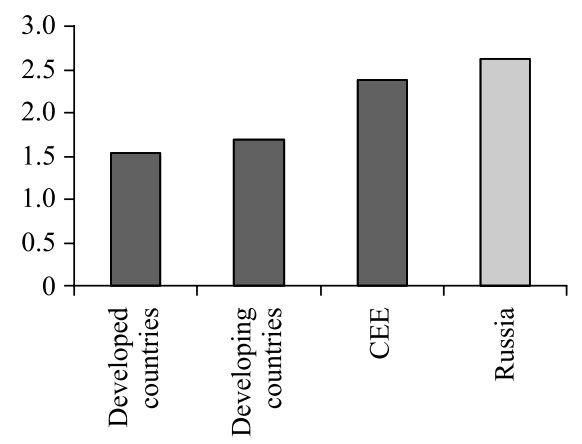

Fig. 7a. Budget expenditures on public order and safety (\% of GDP).

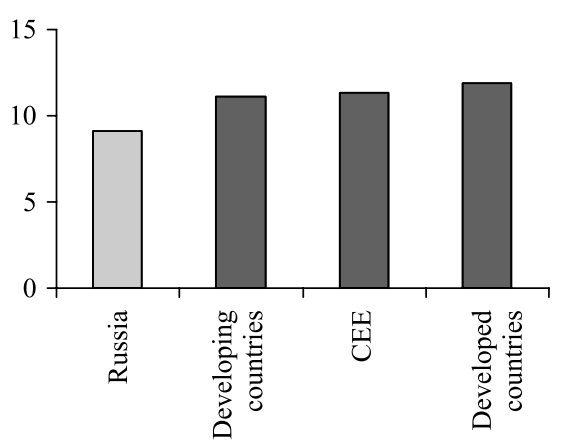

Fig. 5b. Proportion of education expenditures out of total expenditures for the general government (\%).

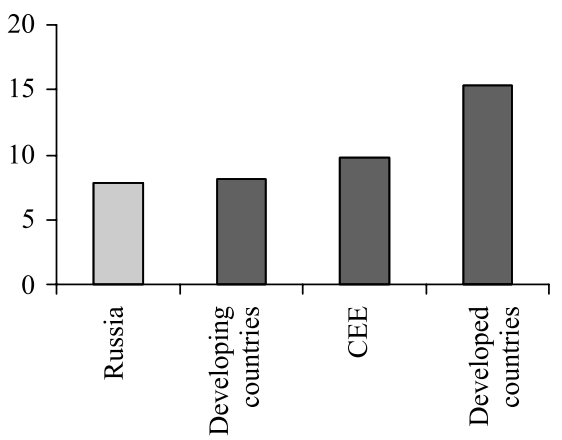

Fig. 6b. Proportion of health care expenditures out of total expenditures by the general government $(\%)$.

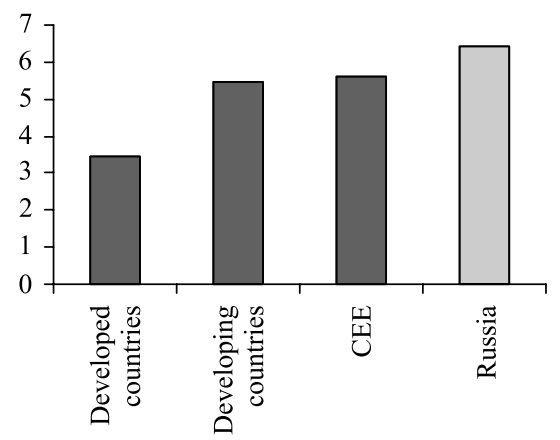

Fig. 7b. Proportion of public order and safety expenditures out of total expenditures for the general government $(\%)$.

lower than in other countries, with an increased level of expenditures on defense and security.

The next aspect of budget modifications is the availability of conditions for economies in non-productive industries. In the law enforcement system and the military, a large number of employees is noted in addition to high expenditures (Table 1). 


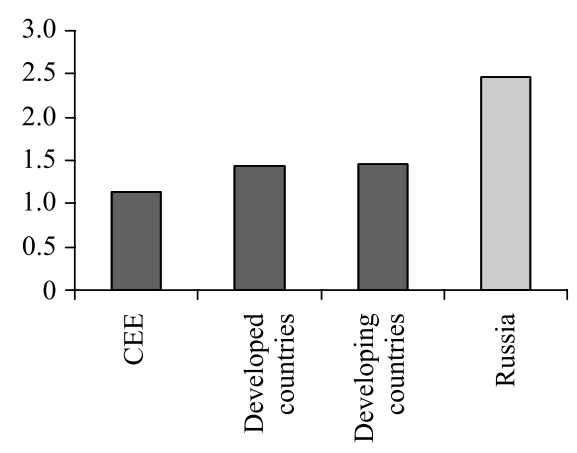

Fig. 8a. Budget expenditures on defense ( $\%$ of GDP).

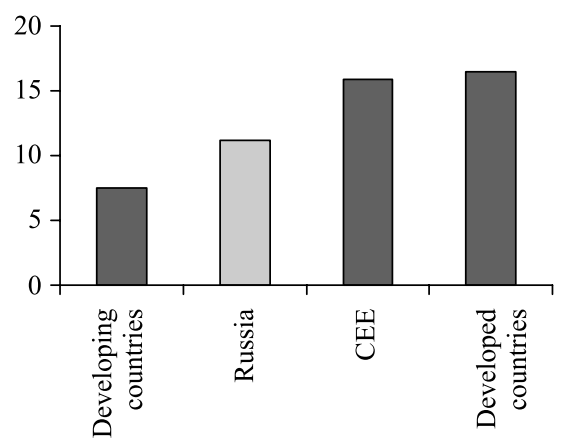

Fig. 9a. Budget expenditures on social protection ( $\%$ of GDP).

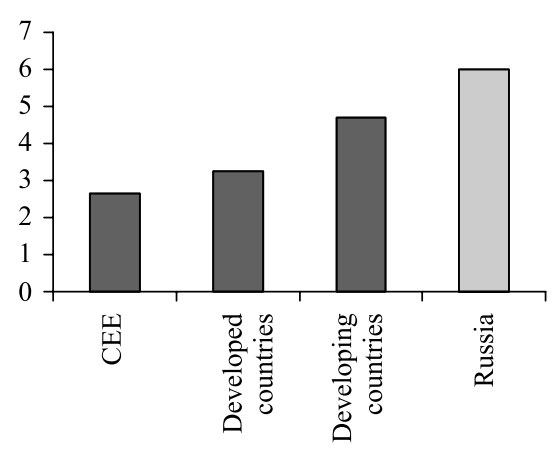

Fig. 8b. Proportion of defense expenditures out of total expenditures for the general government $(\%)$.

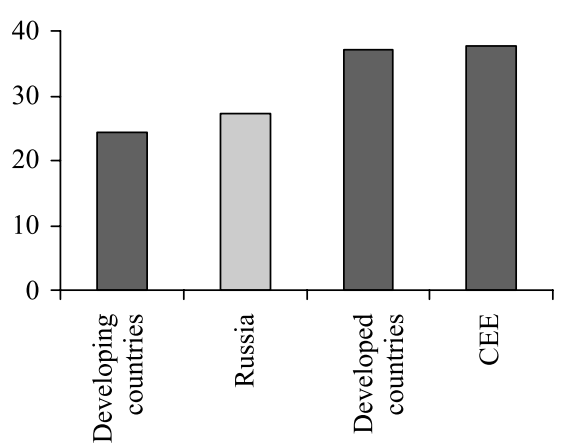

Fig. 9b. Proportion of social protection expenditures out of total expenditures for the general government (\%).

Table 1

Estimated number of servicemen in the armed forces and the law enforcement system per 100,000 people, 2014.

\begin{tabular}{lll}
\hline Country & Servicemen in armed forces & Servicemen in law enforcement \\
\hline Russia & 895 & 521 \\
Developing countries & 577 & 363 \\
Developed countries & 517 & 258 \\
CEE & 500 & 284 \\
\hline
\end{tabular}

Source: Authors' calculation based on World Bank and UN data.

Reforming the law enforcement system requires a substantial optimization of the number of people employed, along with change in its organization, administration system, and incentives for employees. A one-fourth reduction in the number of employees, with a corresponding economy, is acceptable as a target. The Main Guidelines of Fiscal Policy for 2017 through 2019 already provide for reducing expenditures on this item to $2.0 \%$ of GDP. It also appears reasonable to reduce spending further, to $1.8 \%$ of GDP by 2024 , stabilizing it at this level.

The increased procurement of combat vehicles and reform of monetary provisions for servicemen led to a rise in total defense expenditures from $2.6 \%$ to $2.7 \%$ of GDP on average from 2006 to 2011, to $3.8 \%$ of GDP in 2015 and $4.4 \%$ of GDP in 2016. The Law on the Federal Budget for 2017 through 2019 allows for 
a reduction in defense expenditures to $2.9 \%$ of GDP. The subsequent stabilization of the financing for armament procurement as a percentage of GDP will enable maintenance of the overall size of defense expenditures at $2.8 \%$. The drafting of the rank and file from the armed forces can be switched to a voluntary (contract-based) scheme. This will improve the armed forces' combat readiness with minimal distraction for the most active portion of the workforce from economic activity under tough demographic conditions.

The social security system shows huge potential for improving the efficiency of expenditures. According to estimates, over three-fourths of all social benefits (excluding pensions) are received by citizens not falling within the category of the needy. Part of the pension payment also represents social security by its nature. Here, the situation is similar; a substantial portion of social benefits are allocated to pensioners with incomes exceeding the living minimum, or even the average level (Gurvich, Sonina, 2012). Thus, a transition to targeted social protection can ensure a substantial economy of budget funds without prejudice to the fight against poverty. Approximately three-fourths of social security can be provided through a target-based concept and should not use need assessments based on income, but instead use a comprehensive multi-criterion assessment of the well-being of beneficiaries of government support.

An important source for improving the efficiency of the social security system is increasing the retirement age. During the past 11 years, life expectancy grew by 6.5 years in Russia ( 7.5 for males). With the current (falling) proportion between the duration of work and retirement years, it is simply impossible to earn a "decent senior's living." In this case, reform is required to ensure the stability of the budget system to the degree necessary for current and future pensioners; without it, the gap between pensions and wages (excessive already) will continue to grow. To this end, the retirement age should be increased gradually, and the employment duration requirements to qualify for an early pension should be tightened. Accumulative voluntary pension security systems should also be developed. It is important that the range of beneficiaries for this reform be as wide as possible; a portion of the saved funds is earmarked for stabilizing the transfer from the federal budget to the Russian Pension Fund, while another portion is planned for stabilizing the replacement ratio (the ratio of average pension and average wages).

There are also considerable opportunities to reduce expenditures for general public services. A brief glance at the population's spending priorities has been provided through a survey of 6,000 respondents, carried out by the Levada Center at the request of the CSR between December 2016 and January 2017. In answers to the question, "In your opinion, to which areas should the government allocate more funds than now?", the following areas were favored most: health care $(55 \%$ of respondents), transportation development (45\%), social policy (45\%), and preschool and high-school education (44\%). ${ }^{4}$ Thus, except for social policy, which has traditionally found increased public demand, people place priority on increasing productive expenditures.

Expenditures for the national economy require a differentiated approach. Budget expenditures for roads and transportation (infrastructure development)

\footnotetext{
${ }^{4}$ The total number of responses exceeds $100 \%$, as respondents were allowed to choose up to five areas for expenditures.
} 
should be increased by one-third, while a number of other expenditures (having the form of unreasonable subsidies) should be thoroughly optimized. Additional funds for constructing transportation infrastructure will greatly accelerate development at a more technical level, ensuring the creation of a network of highspeed railroads and highways - the implementation of a multi-modal transport integration concept based on transportation and logistics hubs.

By 2024, educational expenditures should be increased by 0.8 to 1.0 p.p. of GDP from the current level. Changes should also be made at all stages of education, from introducing mandatory preparatory schools for children aged 5 to 6 , to creating a network of national research universities that integrate research and education. Other vital areas of education reform include integrating the vocational education system into the applied bachelor's curricula, introducing specialized education in senior high school, and creating and transforming at least 300 hightech colleges and at least 600 multi-specialty colleges.

In health care, the following reforms appear to be promising: re-prioritizing from treatment to prevention, equipping medical facilities with new equipment, implementing chronic disease treatment programs, and developing personal health monitoring. Combined with additional funding, this will increase life expectancy to 76 years (currently 72 years) in the medium term. A reasonable increase in budget expenditures on health care would be 0.7 to 0.8 p.p. of GDP from the current level.

Considering the above, a possible trend among the overall parameters of the Russian budget system is shown in Fig. 10. Budget expenditure trends are shown by main areas in Table 2 . The budget maneuver will result in an increase of productive expenditures by 2.0 to 2.4 p.p. of GDP, while maintaining overall extended government expenditures at around 34\% of GDP, enabling Russia to approach the level of developed countries both in terms of the size of productive expenses and proportion of total expenditures. Judging by the above estimate of the effects of productive expenditures on GDP growth rates $(+0.26$ p.p., according to Gemmell et al., 2011), the contribution of the budget maneuver to accelerating economic growth may reach 0.6 p.p. per year. ${ }^{5}$ As seen from

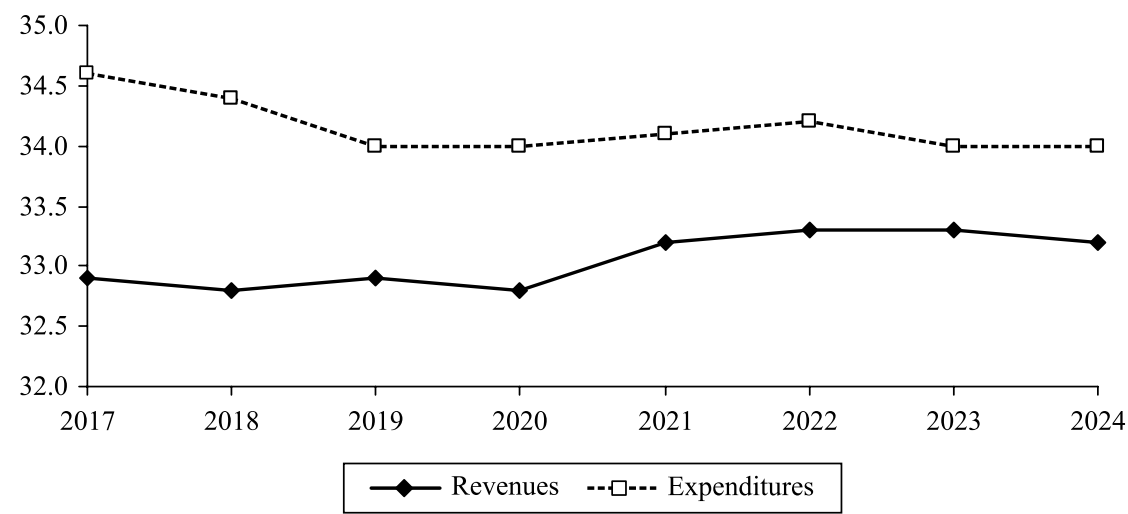

Fig. 10. Target Russian budget system parameters through 2024 ( $\%$ of GDP).

Source: Authors' calculations.

\footnotetext{
${ }^{5}$ An assessment of the effect of budget expenditures on economic growth rates in Russia requires a separate research.
} 
Table 2

Target budget system expenditure indicators during the budget maneuver (\% of GDP).

\begin{tabular}{lrrrrrr}
\hline & 2017 & 2018 & 2019 & 2020 & 2024 & $\begin{array}{l}2024 \text { vs } \\
2017\end{array}$ \\
& & & & & & -0.6 \\
Total expenditures & 34.6 & 34.4 & 34.0 & 34.0 & 34.0 & \\
$\quad$ including: & 2.1 & 2.2 & 2.1 & 2.0 & 1.9 & -0.2 \\
$\quad$ general public services & 3.1 & 3.0 & 2.9 & 2.9 & 2.8 & -0.3 \\
$\quad$ defense & 2.3 & 2.2 & 2.0 & 2.0 & 1.8 & -0.5 \\
public order and safety & 4.2 & 4.3 & 4.4 & 4.6 & 4.6 & 0.4 \\
economic affairs & & & & & & \\
$\quad$ including: & 0.4 & 0.5 & 0.4 & 0.4 & 0.4 & 0.0 \\
$\quad$ agriculture & 1.3 & 1.6 & 1.7 & 1.8 & 2.0 & 0.7 \\
$\quad$ roads & 0.8 & 0.9 & 0.9 & 1.0 & 1.0 & 0.2 \\
$\quad$ transportation & 3.5 & 3.6 & 3.8 & 3.9 & 4.4 & 0.9 \\
education & 3.3 & 3.5 & 3.7 & 3.7 & 4.0 & 0.7 \\
health care & 12.9 & 12.6 & 12.2 & 12.0 & 11.7 & -1.2 \\
social protection & 2.2 & 2.0 & 2.0 & 2.0 & 2.1 & -0.1 \\
$\quad$ other expenditures & 1.0 & 1.0 & 0.9 & 0.9 & 0.7 & -0.3 \\
servicing of national debt & & & & &
\end{tabular}

Source: Authors' calculations.

the analysis by the above authors, this effect will require up to five years to fully reveal itself.

To realize the potential of the proposed budget maneuver, the quality of public administration needs to be significantly improved. The country needs to switch from an inefficient hierarchical system, focused on current problems and mostly "manual" administration, to a modern change management system aimed at achieving strategic objectives for social development. Specific transformations include foregoing excessive regulations, increasing the role of indicators in the governor performance assessment system that characterizes the country's development priorities, and creating a single, transparent HR policy focused on selecting the best candidates and functioning to raise the prestige of civil service.

\section{References}

Acosta-Ormaechea, S., \& Morozumi, A. (2013). Can a government enhance long-run growth by changing the composition of public expenditure? IMF Working Paper, No. WP/13/162.

Adam, C., \& Bevan, L. (2005). Fiscal deficits and growth in developing countries. Journal of Public Economics, 89 (4), 571-597.

Afonso, A., \& Jalles, T. (2013). Fiscal composition and long-term growth. ECB Working Paper Series, No. 1518. Frankfurt am Main: European Central Bank.

Aghion, P., Howitt, P., \& Murtin, F. (2010). The relationship between health and growth: When Lucas meets Nelson-Phelps. NBER Working Paper, No. 15813.

Baldacci, E., Clements, B., Gupta, S., \& Cui, Q. (2008). Social spending, human capital, and growth in developing countries. World Development, 36 (8), 1317-1341.

Barbiero, O., \& Cournède, B. (2013). New econometric estimates of long-term growth effects of different areas of public spending. OECD Economics Department Working Papers, No. 1100.

Barro, R. (1990). Government spending in a simple model of endogenous growth. Journal of Political Economy, 98 (5), 103-125.

Bayrak, M., \& Esen, O. (2014). Examining the validity of Wagner's law in the OECD economies. Research in Applied Economics, 6 (3), 1-16.

Catão, L., \& Terrones, M. (2005). Fiscal deficits and inflation. Journal of Monetary Economics, $52(3), 529-554$. 
Fournier, J., \& Johansson, A. (2016). The effect of the size and the mix of public spending on growth and inequality. OECD Economics Department Working Papers, No. 1344. Paris: OECD Publishing.

Gemmell, N., Kneller, R., \& Sanz, I. (2011). The timing and persistence of fiscal policy impacts on growth: Evidence from OECD countries. Economic Journal, 121 (550), F33-F58.

Goryunov, E., Kazakova, M., Kotlikoff, L., Mamedov, A., Nazarov, V., Nesterova, K., Trunin, P., \& Shpenev, A. (2013). Russia's fiscal gap. NBER Working Paper, No. 19608.

Goryunov, E., Kotlikoff, L., \& Sinelnikov-Murylev, S. (2015). Fiscal gap: An estimate for Russia. Voprosy Ekonomiki, 7, 5-25 (In Russian).

Gurvich, E., \& Sonina, Yu. (2012). Microanalysis of the Russia's pension system. Voprosy Ekonomiki, 2, 27-51 (In Russian).

Idrisov, G., \& Sinelnikov-Murylev, S. (2013). Budget policy and economic growth. Voprosy Ekonomiki, 8, 33-59 (In Russian).

IMF (2014). Is it time for an infrastructure push? The macroeconomic effects of public investment. In: World economic outlook: Legacies, clouds, uncertainties (Ch. 3, pp. 75-114). Washington, DC: International Monetary Fund.

IMF (2015a). Fiscal Monitor. Now is the time: Fiscal policies for sustainable growth. Washington, DC: International Monetary Fund.

IMF (2015b). Fiscal policy and long-term growth (IMF Policy Paper). Washington, DC: International Monetary Fund.

IMF (2017). Fiscal Monitor. Achieving more with less. Washington, DC: International Monetary Fund.

Ivanova, M., Balaev, A., \& Gurvich, E. (2017). Implications of higher retirement age for the labor market. Voprosy Ekonomiki, 3, 22-39 (In Russian).

Kudrin, A., \& Gurvich, E. (2012). Population aging and risks of budget crisis. Voprosy Ekonomiki, 3, 52-79 (In Russian).

Lamartina, S., \& Zaghin, A. (2011). Increasing public expenditure: Wagner's law in OECD countries. German Economic Review, 12 (2), 149-164.

Lin, H.-Y., \& Chu, H.-P. (2013). Are fiscal deficits inflationary? Journal of International Money and Finance, 32 (1), 214-233.

Mau, V. A., \& Kouzminov, Ya. I. (Eds.) (2013). Strategy 2020: A new growth model-new social policy. Moscow: Delo (In Russian).

Ministry of Finance of the Russian Federation (2015). Main guidelines of increasing efficiency of the federal budget expenditures. Moscow (In Russian).

Mourougane, A., Botev, J., Fournier, J.-M., Pain, N., \& Rusticelli, E. (2016). Can an increase in public investment sustainably lift economic growth? OECD Economics Department Working Papers, No. 1351. Paris: OECD Publishing.

OECD (2001). Competition policy in subsidies and state aid. Paris: OECD Publishing.

Wagner, A. (1958 [1883]). Three extracts on public finance. In R. A. Musgrave, \& A. T. Peacock (Eds.), Classics in the theory of public finance (pp. 1-15). London: Macmillan. 